Volume 12, Nomor 2, November 2020, pp 327-336 Copyright (C) 2017

Jurnal Akuntansi, Program Studi Akuntansi, Fakultas Ekonomi, Universitas Kristen Maranatha. ISSN 2085-8698 | e-ISSN 2598-4977. http://journal.maranatha.edu

\title{
Permintaan Investor dan Karakteristik Keuangan Terhadap Keputusan Pembayaran Dividen
}

\author{
Imelia Carolina Tedja ${ }^{1}$ \\ Fakultas Ekonomi dan Bisnis, Universitas Ma Chung \\ Villa Puncak Tidar N-01, Malang 65151, Indonesia \\ imeliacarolina@gmail.com \\ Tarsisius Renald Suganda ${ }^{2}$ \\ Fakultas Ekonomi dan Bisnis, Universitas Ma Chung \\ Villa Puncak Tidar N-01, Malang 65151, Indonesia \\ renald.suganda@machung.ac.id \\ Fitri Oktariani ${ }^{3}$ \\ Fakultas Ekonomi dan Bisnis, Universitas Ma Chung \\ Villa Puncak Tidar N-01, Malang 65151, Indonesia \\ fitri.oktariani@machung.ac.id
}

\begin{abstract}
Dividend payment decision is an essential policy of companies to provide investors' expectation of investment returns. This research is aimed to prove the catering theory of dividend and financial characteristics affecting corporate decisions in dividend payments. The study was conducted on a manufacturing company published on the Indonesia Stock Exchange (IDX). Analyzing the prediction of catering theory and financial analysis of companies in making dividend payments is conducted using the logistic regression method. This research is a quantitative research and moreover manufacturing companies as research sample were used from 2014 to 2018. Financial statements were obtained from the Indonesia Stock Exchange (IDX). The result of this study indicated that investors' demand has positive effect on dividend payment decisions. Hence, companies consider catering in dividend payment decisions. While corporate financial characteristics such as free cash flow have positive effect on dividend payment decisions, profitability has no influence on dividend payment decisions and moreover, leverage has a negative influence on dividend payment decisions.
\end{abstract}

Keywords: Catering Theory, Investor Demand, Free Cash Flow, Profitability, Leverage 


\begin{abstract}
Abstrak
Keputusan pembayaran dividen merupakan kebijakan yang penting dilakukan untuk memenuhi harapan investor terhadap imbal hasil investasi. Tujuan dari penelitian ini adalah untuk menguji prediksi teori catering dividen dan karakteristik keuangan yang memiliki pengaruh terhadap keputusan yang diambil perusahaan dalam membagikan dividen. Penelitian difokuskan pada perusahaan-perusahaan manufaktur yang terdaftar di Bursa Efek Indonesia (BEI). Metode pengujian prediksi teori catering dan karakteristik keuangan perusahaan dalam melakukan pembayaran dividen dilakukan dengan melakukan analisis regresi logistik. Jenis penelitian ini adalah penelitian kuantitatif dan perusahaan manufaktur sebagai sampel penelitian digunakan mulai tahun 2014 sampai dengan 2018. Laporan keuangan didapatkan dari Bursa Efek Indonesia (BEI). Hasil penelitian ini memberikan bukti bahwa permintaan investor berpengaruh positif terhadap keputusan pembayaran dividen. Oleh karena itu, dapat dikatakan bahwa perusahaan manufaktur mempertimbangkan perilaku catering dalam keputusan pembayaran dividen.Sementara karakteristik keuangan perusahaan seperti arus kas bebas memiliki pengaruh positif terhadap keputusan pembayaran dividen, profitabilitas tidak memiliki pengaruh terhadap keputusan pembayaran dividen, dan lebih lanjut, leverage memiliki pengaruh negatif terhadap keputusan pembayaran dividen.
\end{abstract}

Kata Kunci: Teori Catering, Permintaan Investor, Arus Kas Bebas, Profitabilitas, Leverage

\section{Pendahuluan}

Tujuan investor dalam menginvestasikan modalnya adalah menghasilkan pendapatan atau tingkat kembalian investasi atau return (Rahmawati et al., 2014). Menurut Fahmi (2014), return adalah keuntungan yang diperoleh investor dari hasil kebijakan investasi saham yang dilakukannya. Return yang akan didapatkan oleh investor salah satunya adalah dividen yang merupakan laba usaha yang diperoleh dan diberikan perusahaan kepada investor sebagai imbalan atas kesediaan investor untuk menanamkan hartanya pada perusahaan tersebut (Rudianto, 2012). Sedangkan keputusan untuk menentukan apakah laba yang diperoleh perusahaan akan dibagi kepada pemegang saham sebagai dividen atau akan ditahan dalam bentuk saldo laba merupakan bagian dari kebijakan dividen (Rusli \& Sudhiarta, 2017).

Kebijakan pembayaran dividen memiliki dampak terhadap pemegang saham dan perusahaan yang membagikan dividen. Bagi para pemegang saham, pembagian dividen yang relatif stabil dari perusahaan dapat meminimalisir ketidakpastian akan hasil yang diharapkan atas investasi yang dilakukan. Namun, bagi perusahaan penerapan kebijakan ini dapat menjadi suatu permasalahan. Dalam hal ini, pihak manajemen perusahaan dituntut untuk mengambil keputusan yang dapat menghasilkan keseimbangan antara kepentingan pemegang saham dan perusahaan.

Menurut Sugesta (2017), penentuan kebijakan dividen dipengaruhi juga oleh karakteristik keuangan seperti free cash flow, profitabilitas, dan leverage. Free cash flow yang dimiliki oleh perusahaan biasanya menunjukkan kas yang tersedia bagi investor. Profitabilitas merupakan salah satu ukuran yang mencerminkan lancarnya pembayaran dividen kepada investor. Leverage merupakan utang yang dipakai oleh perusahaan untuk menjalankan kegiatan operasionalnya dan digunakan 
untuk memberi gambaran perusahaan kepada investor.

Teori mengenai kebijakan dividen terus mengalami perkembangan dan salah satunya adalah teori catering dividen (catering theory of dividend). Teori ini merupakan pengembangan asumsi dari teori irelevansi dividen yang dikemukakan oleh Miller \& Modigliani (1961). Teori ini menyatakan bahwa kebijakan dividen perusahaan didorong oleh permintaan investor terhadap pembayaran dividen sehingga manajemen perusahaan akan melayani investor dengan membayar dividen ketika premi dividen tinggi.

Bukti terhadap pelaksanaan teori catering ini masih terbatas, namun hasil temuan oleh Denis \& Osobov (2008) yang menyatakan bahwa di negara common law seperti Kanada dan Inggris pemegang saham memberikan tekanan yang kuat pada manajer terbukti mendukung teori catering meskipun tingkat signifikansi yang ditemukan rendah. Di sisi lain, pada negara civil law yaitu seperti Jerman, Jepang, dan Perancis, para pemegang sahamnya memberikan tekanan yang rendah pada manajer dan pada akhirnya menunjukkan penolakan terhadap teori ini. Hal ini sejalan dengan penelitian Tsuji (2011) yang melakukan pengujian terhadap teori catering dividen di perusahaan industri kimia dan peralatan elektronika di negara Jepang. Temuan penelitiannya adalah bahwa manajer-manajer perusahaan tidak mempertimbangkan perilaku catering sebagai faktor penentu kebijakan pembayaran dividen. Sebaliknya, Neves et al., (2011) menemukan bahwa sentimen para investor di Eropa memiliki efek terhadap besaran pembayaran dividen.

Penelitian ini merupakan modifikasi dari penelitian Fatmawati \& Ahmad (2017). Dalam penelitian ini, variabel yaitu insentif catering dapat digunakan sebagai faktor yang mempengaruhi pembayaran dividen di Indonesia. Perusahaan manufaktur dijadikan sebagai sampel karena sebanyak $41 \%$ perusahaan yang tergabung dalam BEI merupakan perusahaan-perusahaan manufaktur yang secara lebih dalam diketahui bahwa perusahaan di sektor ini seringkali membagikan dividen kepada para pemegang sahamnya.

Free cash flow yang dimiliki perusahaan menunjukkan kas yang tersedia bagi investor. Perusahaan yang membagikan dividen secara tunai akan sangat bergantung pada posisi kas yang tersedia (Aristantia \& Putra, 2015). Perusahaan dengan laba yang tinggi namun nilai free cash flow rendah, memungkinkan bahwa perusahaan tersebut tidak dapat membayarkan dividennya.

Menurut PSAK No. 2 Revisi Tahun 2014, arus kas dari aktivitas investasi mencerminkan penerimaan dan pengeluaran kas yang berhubungan dengan sumber daya yang diperoleh perusahaan ditujukan untuk menghasilkan pendapatan dan arus kas masa depan. Pembayaran dividen yang dilakukan perusahaan merupakan aktivitas arus kas keluar. Semakin kuat posisi kas perusahaan memberikan makna bahwa semakin tinggi tingkat kemampuan yang dimiliki oleh perusahaan dalam membagikan dividennya kepada investor.

Perolehan laba yang tinggi dalam suatu perusahaan juga akan menjadi sinyal bagi investor dalam melakukan kegiatan investasinya. Salah satu ukuran yang digunakan untuk mengetahui kemampuan perusahaan dalam menghasilkan laba dan untuk melihat seberapa besar tingkat keefektifan manajemen dalam mengelola perusahaan dilihat dari tingkat profitabilitas (Syahyunan, 2013). Semakin tinggi tingkat profitabilitas mencerminkan lancarnya pembayaran dividen kepada investor. Hal ini dikarenakan manajemen efektif dalam mengelola perusahaan sehingga tidak mengalami kesulitan dalam mengembalikan utang jangka pendek maupun utang jangka panjang.

Utang yang dipakai oleh perusahaan untuk menjalankan kegiatan operasionalnya dan digunakan untuk memberi gambaran perusahaan kepada investor disebut dengan 
leverage. Leverage diproksikan dengan Debt to Equity Ratio (DER). Semakin besar Debt to Equity Ratio menandakan struktur permodalan usaha lebih banyak memanfaatkan utang dibandingkan dengan ekuitas. Penggunaan utang yang banyak menandakan semakin besarnya beban tetap berupa angsuran pinjaman pokok dan bunga yang harus dibayar. Apabila perusahaan melakukan pelunasan utangnya dengan menggunakan dana dari saldo laba, itu berarti perusahaan harus memprioritaskan sebagian besar dari pendapatannya untuk melunasi utang tersebut. Sehingga hal ini dapat mengakibatkan penundaan pembayaran dividen.

Penelitian ini bertujuan untuk menginvestigasi apakah teori catering telah diterapkan pada perusahaan manufaktur yang terdaftar di BEI dengan permintaan investor sebagai proksinya. Free cash flow diproksikan dengan arus kas dari operasi dikurangi dengan belanja modal. Porfitabilitas diproksikan dengan Return on Equity (ROE) dan leverage diproksikan dengan Debt to Equity Ratio (DER).

\section{Kerangka Teoritis dan Hipotesis}

\section{Catering Theory of Dividend}

Teori Catering (Catering Theory of Dividend) menjelaskan bahwa keputusan perusahaan dalam membayar dividennya didorong oleh permintaan investor. Perusahaan membayarkan dividen ketika investor menempatkan premi pada perusahaan yang membayar dividen (payers) dan menghilangkan dividen ketika investor menunjukkan preferensi pada perusahaan yang tidak membayar dividen (non payers) (Baker \& Wurgler, 2004).

Teori ini memiliki perhatian terhadap permintaan pasar atas saham dalam bentuk pembayaran dividen oleh perusahaan. Hal utama yang diprediksi dari teori ini adalah kecenderungan perusahaan dalam membayarkan dividennya tergantung pada premi dividen yang terukur dari harga saham yang dapat dikalkulasi melalui formula market to book ratio.

\section{Dividen}

Dividen merupakan pembagian laba atau keuntungan yang dilakukan oleh suatu perseroan kepada pemegang saham atas keuntungan yang diperoleh perusahaan (Halim, 2015). Sedangkan menurut Hanafi, et al., (2016) dividen merupakan suatu kompensasi yang diberikan kepada para pemegang saham di samping perolehan capital gain.

Jenis dividen menurut Hanafi (2014), yang dapat dibagikan oleh perusahaan kepada investor adalah cash dividend dimana dividen akan diberikan dalam bentuk uang tunai. Script dividend merupakan suatu surat berbunga tanda kesediaan membayar sejumlah uang tertentu yang diberikan perusahaan kepada investor. Property dividend yaitu dividen yang akan diberikan dalam bentuk barang. Stock dividend adalah dividen yang akan diberikan dalam bentuk saham yang dikeluarkan oleh perusahaan itu sendiri. Liquidating dividend merupakan dividen yang dibayarkan dimana sebagian persentase dari jumlah tersebut dipergunakan sebagai pembayaran dari bagian laba, sedangkan sebagian persentase lainnya ditujukan untuk pengembalian modal perusahaan.

\section{Kebijakan Dividen}

Kebijakan dividen merupakan peluang tentang berapa besar laba yang diperoleh dalam suatu periode akan dibagikan kepada pemegang saham dalam bentuk dividen dan akan ditahan dalam bentuk laba ditahan (Halim, 2015). Proksi yang digunakan dalam kebjiakan dividen adalah dividend yield dan dividend payout.

\section{Faktor yang Memengaruhi Kebijakan Dividen}

Penentuan kebijakan dividen dipengaruhi juga oleh karakteristik keuangan seperti free cash flow, profitabilitas, dan leverage 
(Sugesta, 2017). Free cash flow yang dimiliki perusahaan menunjukkan kas yang tersedia bagi investor. Profitabilitas digunakan untuk mengetahui kemampuan perusahaan dalam menghasilkan laba dan melihat tingkat kefektifan manajemen dalam mengelola perusahaan. Sedangkan leverage merupakan besaran utang perusahaan yang dimaksudkan untuk menjalankan kegiatan operasional perusahaan sekaligus untuk memberi gambaran perusahaan pada investor terkait kondisi keuangan perusahaan.

\section{Pengembangan Hipotesis}

\section{Pengaruh Permintaan Investor Terhadap Keputusan Pembayaran Dividen}

Prediksi utama dari Catering Theory of Dividend adalah kecenderungan untuk membayar dividen yang bergantung pada premi dividen yang dapat terukur dari harga saham dan dapat dihitung dengan market to book ratio. Market to book ratio merupakan rasio yang digunakan sebagai indikator untuk mengukur kinerja perusahaan melalui harga pasarnya (Hanafi, et. al., 2016). Perusahaan yang memiliki nilai market to book ratio tinggi mengindikasikan bahwa pasar menghargai saham perusahaan relatif lebih rendah daripada nilai buku perusahaan tersebut. Rendahnya nilai pasar terhadap saham perusahaan membuat kecilnya keuntungan (return) yang didapatkan oleh investor. Berdasarkan uraian tersebut, maka hipotesis yang dirumuskan sebagai berikut.

\section{H1: Permintaan investor berpengaruh positif terhadap keputusan pembayaran dividen.}

Pengaruh Free Cash Flow terhadap Keputusan Pembayaran Dividen

Menurut PSAK No. 2 Revisi Tahun 2014, arus kas dari aktivitas investasi mencerminkan penerimaan dan pengeluaran kas yang berhubungan dengan sumber daya yang diperoleh perusahaan ditujukan untuk menghasilkan pendapatan dan arus kas masa depan. Pembayaran dividen yang dilakukan perusahaan merupakan aktivitas arus kas keluar. Semakin kuat posisi kas perusahaan itu menandakan bahwa semakin besar kemampuan yang dimiliki perusahaan untuk membayarkan dividen kepada investor. Hasil penelitian yang dilakukan oleh Wedhana \& Wiksuana (2015), mengenai pengaruh kepemilikan institusional, free cash flow, leverage, dan profitabilitas terhadap kebijakan dividen menyatakan bahwa terdapat hubungan positif antara free cash flow terhadap keputusan pembayaran dividen.Berdasarkan uraian tersebut, maka hipotesis yang dirumuskan sebagai berikut.

\section{H2: Free cash flow berpengaruh positif terhadap keputusan pembayaran dividen.}

\section{Pengaruh Profitabilitas Terhadap Keputusan Pembayaran Dividen}

Menurut Syahyunan (2013), profitabilitas merupakan salah satu ukuran yang digunakan untuk mengetahui kemampuan perusahaan dalam menghasilkan laba dan seberapa besar tingkat keefektifan manajemen dalam melakukan pengelolaan pada perusahaannya. Hasil penelitian yang dilakukan oleh Fatmawati \& Ahmad (2017) mengenai dampak profitabilitas terhadap kebijakan dividen memberikan temuan bahwa perusahaan yang membagikan dividen memiliki tingkat profitabilitas yang besar. Hal ini juga didukung oleh penelitian Harun \& Jeandry (2018) yang menyatakan bahwa profitabilitas berpengaruh positif terhadap kebijakan dividen. Berdasarkan uraian tersebut, maka hipotesis yang dirumuskan sebagai berikut.

\section{H3: Profitabilitas berpengaruh positif terhadap keputusan pembayaran dividen.}


Pengaruh Leverage Terhadap Keputusan Pembayaran Dividen

Leverage merupakan salah satu ukuran yang digunakan untuk mengetahui seberapa besar tingkat utang yang dimiliki oleh perusahaan. Leverage juga menunjukkan risiko yang dihadapi perusahaan, semakin besar risiko yang dihadapi oleh perusahaan maka ketidakpastian untuk menghasilkan laba dimasa depan juga akan meningkat (Tarjo, 2008). Penelitian yang dilakukan Wedhana \& Wiksuana (2015) menemukan bahwa leverage berpengaruh negatif dan signifikan terhadap kebijakan dividen. Penelitian serupa yang dilakukan oleh Eltya et al., (2016) juga menyatakan bahwa leverage berdampak negatif terhadap kebijakan dividen. Berdasarkan uraian tersebut, maka hipotesis yang dirumuskan sebagai berikut.

\section{H4: Leverage berpengaruh negatif terhadap keputusan pembayaran dividen.}

Model kerangka konseptual adalah sebagai berikut.

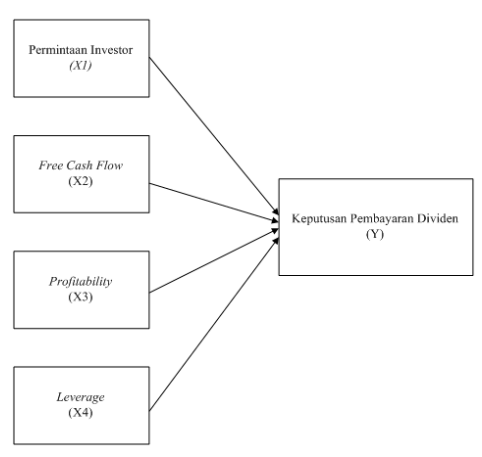

Gambar 1

Kerangka Konseptual

Skema hubungan antara keputusan pembayaran dividen dengan variabel $\mathrm{x}$ yang mempengaruhinya dijelaskan sebagai berikut.

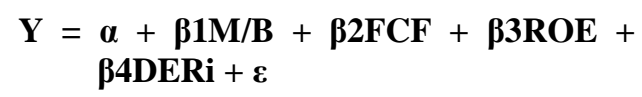

Keterangan:

$\mathrm{M} / \mathrm{B}=$ Rasio pasar per nilai buku

FCF $=$ Free Cash Flow

$\mathrm{ROE}=$ Return on Equity

DER =Debt to Equity Ratio

$\alpha=$ Konstanta

$\beta 1, \beta 5=$ Koefisien regresi

$\varepsilon \quad=$ Errors

\section{Metode Penelitian}

\section{Jenis Penelitian}

Jenis penelitian dalam penelitian ini adalah penelitian kuantitatif yang bermakna bahwa penelitian kuantitatif merupakan penelitian yang mencoba melakukan pengukuran akurat terhadap sesuatu (Cooper \& Schindler, 2014). Menurut Ulber (2015), penelitian dengan bentuk hubungan kausalitas menjelaskan pengaruh perubahan variasi nilai dalam suatu variabel terhadap perubahan variasi nilai variabel lain.

\section{Populasi dan Sampel}

Populasi dalam penelitian ini adalah perusahaan manufaktur yang terdaftar di Bursa Efek Indonesia (BEI) selama tahun 2014 sampai dengan tahun 2018. Kriteria sampel yang digunakan dalam penelitian ini adalah sebagai berikut. (1) Perusahaan manufaktur yang terdaftar di BEI selama periode penelitian yaitu pada tahun 2014 sampai tahun 2018, (2) Perusahaan manufaktur yang menyajikan laporan keuangan dan data saham secara lengkap serta menyajikan informasi yang dibutuhkan dalam penelitian selama tahun 2014 sampai dengan tahun 2018. 


\section{Hasil Penelitian dan Pembahasan}

\section{Uji Regresi Logistik}

Menurut Ghozali (2016), regresi logistik digunakan untuk menguji apakah probabilitas terjadinya variabel terikat dapat diprediksi dengan variabel independennya. Pada penelitian ini, model regresi logistik digunakan untuk melihat pengaruh variabel independen terhadap variabel dependen. Berikut merupakan hasil koefisien model regresi logistik pada penelitian ini.

Tabel 1

Hasil Pengujian Regresi Logistik

\begin{tabular}{|c|l|c|c|}
\hline No. & Variabel & B & $\begin{array}{c}\text { Std. } \\
\text { Error }\end{array}$ \\
\hline 1 & $\begin{array}{l}\text { Permintaan } \\
\text { Investor }\end{array}$ & 0,370 & 0,139 \\
\hline 2 & $\begin{array}{l}\text { Free Cash } \\
\text { Flow }\end{array}$ & 0,271 & 0,070 \\
\hline 3 & Profitabilitas & 0,127 & 0,147 \\
\hline 4 & Leverage & $-0,608$ & 0,140 \\
\hline \multicolumn{2}{|l|}{ Constant } & $-6,451$ & 1,865 \\
\hline
\end{tabular}

Sumber Tabel: data olahan, 2020

Berdasarkan hasil koefisien regresi logistik pada tabel diatas, ditunjukkan nilai dari koefisien regresi dari masing-masing variabel. Model regresi yang terbentuk dari nilai koefisien regresi dengan $\alpha=0,05$ adalah sebagai berikut.

\section{$\mathrm{Y}=-6,451+0,370 \mathrm{MB}+0,271 \mathrm{FCF}+$ 0,127 ROE + 0,608 DER}

\section{Uji Hipotesis}

Pengujian signifikansi akan dilakukan untuk menginvestigasi pengaruh sebuah variabel independen terhadap variabel dependennya (secara individual). Pada model binary logit, interpretasi penting yang ada dalam model regresi adalah koefisien Exp. (B). Pengujian ini dilakukan dengan batasan tingkat signifikansi yaitu $0,05(\alpha=5 \%)$. Penerimaan atau penolakan hipotesis ditentukan pada nilai sig. Apabila nilai sig > 0,05 maka hipotesis ditolak (koefisien regresi tidak signifikan).

Tabel 2

Hasil Pengujian Hipotesis

\begin{tabular}{|c|l|c|c|}
\hline No & \multicolumn{1}{|c|}{ Variabel } & B & Sig. \\
\hline 1 & $\begin{array}{l}\text { Permintaan } \\
\text { Investor }\end{array}$ & 0,070 & 0,008 \\
\hline 2 & Free Cash Flow & 0,051 & 0,000 \\
\hline 3 & Profitabilitas & 0,031 & 0,259 \\
\hline 4 & Leverage & $-0,118$ & 0,000 \\
\hline
\end{tabular}

Sumber Tabel: data olahan, 2020

\section{Pembahasan}

\section{Prediksi Teori Catering Terhadap Keputusan Pembayaran Dividen Perusahaan Manufaktur}

Berdasarkan hasil pengujian hipotesis, permintaan investor berpengaruh terhadap keputusan pembayaran dividen. Yang berarti bahwa permintaan investor dapat memengaruhi keputusan pembayaran dividen yang ditentukan oleh perusahaan. Hal ini bermakna bahwa $\mathrm{H}_{0}$ ditolak dan $\mathrm{H}_{\mathrm{a}}$ diterima.

Temuan penelitian ini sejalan dengan yang dilakukan oleh Denis \& Osobov (2008), yang menunjukkan bahwa Kanada dan Inggris dimana para pemegang saham memberikan tekanan yang cukup kuat terhadap manajer. Teori catering terverifikasi dengan signifikansi yang kecil.

Berbeda dengan hasil penelitian yang dilakukan oleh Fatmawati \& Ahmad, (2017) yang menyatakan bahwa permintaan investor tidak berpengaruh signifikan terhadap keputusan pembayaran dividen perusahaan. Ferris, et al., (2009) menyatakan bahwa manajer di negaranegara civil law (termasuk Indonesia) tidak mengikuti preferensi permintaan investor akan keputusan pembayaran dividen karena perlindungan hak investor cenderung lemah bagi investor minoritas.

Penelitian ini menggunakan sampel perusahaan manufaktur tahun 2014 sampai dengan tahun 2018 dan berhasil membuktikan bahwa perusahaan 
manufaktur mempertimbangkan perilaku catering dalam menerapkan kebijakan dividennya. Oleh karena itu, berdasarkan temuan pada penelitian ini, dapat dinyatakan bahwa teori catering memang berlaku di Indonesia.

\section{Pengaruh Free Cash Flow Terhadap Keputusan Pembayaran Dividen}

Hasil pengujian menunjukkan bahwa free cash flow berpengaruh secara positif terhadap keputusan dividen. Faktor yang menyebabkan free cash flow berpengaruh secara signifikan terhadap keputusan pembayaran dividen perusahaan adalah bahwa perusahaan membayarkan dividennya pada saat memiliki arus kas bebas yang tinggi selama lima tahun berturut-turut. Bukti bahwa free cash flow tinggi selama periode penelitian tersebut ditunjukkan oleh perusahaan-perusahaan seperti Arwana Citramulia Tbk, Astra International Tbk, Indocement Tunggal Prakarsa Tbk, Kalbe Farma Tbk, Mulia Industrindo Tbk, Nippon Indosari Corpindo Tbk, PT Industri Jamu dan Farmasi Sido Muncul Tbk, PT Semen Baturaja (Persero) Tbk, Siantar Top Tbk, Tempo Scan Pacific Tbk, Unilever Indonesia Tbk. Perusahaanperusahaan tersebut membayarkan dividen selama tahun penelitian yaitu tahun 2014 sampai dengan tahun 2018.

Hasil penelitian ini sejalan dengan penelitian sebelumnya yang dilakukan oleh Auditta, et al., (2014) yang menyatakan bahwa free cash flow berpengaruh terhadap keputusan pembayaran dividen. Namun penelitian ini bertentangan dengan penelitian yang dilakukan oleh Fatmawati \& Ahmad (2017) yang menemukan bahwa free cash flow tidak berpengaruh terhadap keputusan pembayaran dividen.

\section{Pengaruh Profitabilitas Terhadap Keputusan Pembayaran Dividen}

Hasil pengujian menunjukkan bahwa profitabilitas yang diukur dengan proksi Return on Equity (ROE) tidak berpengaruh terhadap keputusan pembayaran dividen yang dilakukan oleh perusahaan manufaktur yang terdaftar di BEI. Dalam hal ini, profitabilitas yang diproksikan dengan ROE digunakan untuk mengukur kemampuan perusahaan dalam menghasilkan laba berdasarkan modal saham dan merupakan ukuran profitabilitas dari sudut pandang investor. Meskipun rasio ini dianggap sebagai indikator yang menarik bagi para investor untuk berinvestasi, rasio ini bukan merupakan proksi return investor yang sebenarnya. Hal ini dikarenakan, rasio ini secara umum menunjukkan efisiensi manajemen dalam mengelola usaha. Serta rasio ini tidak menghitungkan dividen maupun capital gain untuk investor.

Dengan demikian, hasil penelitian ini memberikan temuan yang sama seperti penelitian Sandy \& Nur (2013) yang menyatakan bahwa profitabilitas tidak berpengaruh terhadap keputusan pembayaran dividen.

\section{Pengaruh Leverage Terhadap Keputusan Pembayaran Dividen}

Berdasarkan hasil pengujian, leverage terbukti memiliki pengaruh negatif terhadap keputusan pembayaran dividen. Penerimaan terhadap hipotesis ini menandakan bahwa semakin tinggi nilai leverage maka akan semakin besar pula risiko yang akan dihadapi dan semakin besar return yang diharapkan. Hal ini disebabkan oleh karena perusahaan berfokus untuk melakukan pemenuhan liabilitasnya terlebih dahulu. Kondisi ini juga berkaitan dengan pengujian pada hipotesis ketiga yang menyatakan bahwa perusahaan lebih memprioritaskan perolehan labanya untuk pembayaran utang daripada pembayaran dividen kepada investor.

Hasil penelitian ini sejalan dengan penelitian yang telah dilakukan oleh Wedhana \& Wiksuana (2015) dan Eltya, et al., (2016) yang menyatakan bahwa Debt to Equity Ratio berpengaruh negatif terhadap keputusan pembayaran dividen. Semakin tinggi tingkat utang maka kemampuan 
perusahaan untuk membayarkan dividennya kepada para investor akan semakin kecil.

\section{Simpulan dan Saran}

\section{Simpulan}

Tujuan penelitian ini adalah untuk membuktikan keputusan perusahaan dalam melakukan pembayaran dividen yang dipengaruhi oleh teori catering dan karakteristik keuangan. Berdasarkan hasil penelitian, dapat diambil kesimpulan bahwa pertama, Catering Theory mampu mempengaruhi keputusan perusahaan dalam membagikan atau membayarkan dividen. Hal ini bermakna bahwa perusahaan manufaktur yang terdaftar di BEI mempertimbangkan permintaan investor dalam keputusan pembayaran dividennya. Sehingga, dalam penelitian ini, teori catering terbukti yaitu bahwa kebijakan pembagian dividen perusahaan ternyata didorong oleh permintaan investor sehingga pihak manajemen perusahaan akan memperhatikan permintaan investor tersebut dengan melakukan pembagian atau pembayaran dividen ketika premi dividen tinggi.

\section{Saran}

Penelitian ini menggunakan sampel perusahaan manufaktur tanpa melakukan pengelompokan berdasarkan sektor industrinya. Guna mendapatkan hasil yang lebih spesifik, maka saran yang bisa diberikan adalah melakukan pemetaan per sektor industri.

\section{Daftar Pustaka}

Aristantia, D., \& Putra, I, M, P, D. (2015). Investment Opportunity Set dan Free Cash Flow pada Tingkat Pembayaran Dividen Perusahaan Manufaktur. E-Jurnal Akuntansi Universitas Udayana, 11, 220-234.

Auditta, I Gede, Sutrisno, dan M. Achsin. 2014. Pengaruh Agency Cost terhadap
Kebijakan Dividen. Jurnal Aplikasi Manajemen, 12 (2): 284-294.

Baker, M., \& Wurgler, J. (2004). “A Catering Theory of Dividend". The Journal of Finance 59(3), pp.11251165.

Cooper, D.R., \& Schindler, P.S. (2014) "Business Research Methods". New York: Mc Graw-Hill.

Denis, D. J., \& Osobov. (2008). "Why Do Firm's Pay Dividens? International Evidence on the Determinants of Dividend Policy". Journal of Financial Economics 89(1), pp.6282.

Eltya, S., Topowijono., \& Azizah, D.F. (2016). "Pengaruh Leverage, Likuiditas, Profitabilitas dan Ukuran Perusahaan terhadap Kebijakan Dividen (Studi pada Perusahaan Perbankan yang Terdaftar di Bursa Efek Indonesia Periode 20122014)". Jurnal Administrasi Bisnis 38(2), pp.55-62.

Fahmi, I. (2014). "Analisis Laporan Keuangan”. Bandung: Alfabeta.

Fatmawati., \& Ahmad, R. (2017). "Teori Catering dan Karakteristik Keuangan dalam Keputusan Dividen Perusahaan BUMN di Indonesia". Ekuitas: Jurnal Ekonomi dan Keuangan, pp. 325-341.

Ferris, S. P., N. Jayaraman, dan S. Sabherwal. 2009. Catering Corporate Dividend Policy: The International Evidence. Journal of Banking \& Finance 33 (9): 1730-1738.

Ghozali, I. (2016). “Aplikasi Analisis Multivariate dengan Program IBM SPSS 23 (Edisi 8) Cetakan ke VIII". Semarang: Badan Penerbit Universitas Diponegoro.

Hanafi, M. M. (2014). "Manajemen Keuangan Edisi 1". Yogyakarta: BPFE, UGM.

Hanafi, M, M \& Halim, A. (2016). Analisis Laporan Keuangan. Edisi Kelima. Yogyakarta: UPP STIM YKPN. 
Halim, A. (2015). "Manajemen Keuangan Bisnis: Konsep dan Aplikasinya”. Jakarta: Mitra Wacana Media.

Harun, S., \& Jeandry, G. (2018). Pengaruh Profitabilitas, Free Cash Flow, Leverage, Likuiditas, dan Size terhadap Dividend Payout Ratio pada Perusahaan Manufaktur yang Terdaftar di Bursa Efek Indonesia. Jurnal Riset Akuntansi, 5, 122-137.

Ikatan Akuntan Indonesia. 2014. Standar Akuntansi Keungan Per Efektif 1 Januari 2015. Jakarta: Ikatan Akuntan Indonesia.

Miller, M. H. \& Modiglani. (1961). "Dividend Policy, Growth, and the Valuation of Shares". The Journal of Business 34(4), pp.441-433.

Neves, E., Pindado, J. C. de la Torre. (2011). " Dividends: New Evidence on the Catering Theory". http://www.eco.uva.es/empresa/uplo ads/dt_14_06.pdf.

Rahmawati, N. D., Saerang, J. S., Rate, P. V. (2014). "Kinerja Keuangan Pengaruhnya terhadap Kebijakan Dividen pada Perusahaan BUMN di Bursa Efek Indonesia". Jurnal EMBA, 2, pp.1306-1317.

Rudianto. (2012). "Pengantar Akuntansi Konsep dan Teknik Penyusunan Laporan Keuangan”. Jakarta: Erlangga.

Rusli, E., \& Sudiartha, G. M. (2017). "Pengaruh Struktur Kepemilikan, Leverage, Pertumbuhan Perusahaan dan Efektivitas Usaha terhadap Kebijakan Dividen”. E-Jurnal Manajemen Unud, pp.5348-5376.

Sandy, A., \& Nur, F. A. (2013). " Pengaruh Profitabilitas, Likuiditas terhadap Kebijakan Dividen Kas pada Perusahaan Otomotif". Jurnal Ilmu dan Riset Akuntansi 1(1).

Santoso, S. (2012). "Panduan Lengkap SPSS Versi 20”. Jakarta: PT Elex Media Komputindo.

Sugesta, R. P. (2017) "Pengaruh Free Cash Flow, Profitabilitas, Likuiditas,
Kebijakan Utang, dan Collateralizable Assets terhadap Kebijakan Dividen (Studi Empiris pada Perusahaan Manufaktur yang Terdaftar di BEI Tahun 20122014)". Skripsi, Fakultas Ekonomi dan Bisnis Universitas Muhammadiyah Surakarta.

Syahyunan. (2013). "Manajemen

Keuangan I: Perencanaan, Analisis, dan Pengendalian Keuangan". Medan: USU Press.

Tarjo. (2008). "Pengaruh Konsentrasi Kepemilikan Institusional dan Leverage terhadap Manajemen Laba, Nilai Pemegang Saham serta Cost of Equity Capital". Simposium Nasional Akuntansi, XI, Pontianak.

Tsuji, C. (2011). "Exploring the Corporate Dividend Payment Behavior of the Japanese Chemicals Industry Firms". The Open Business Journal, 4, 1-13.

Ulber, S. (2015). "Metode Penelitian Sosial”. Bandung: PT Refika Aditama. Wedhana, N. A. N. S., \& Wiksuana, I. G. B. (2015). "Determinasi Kebijakan Dividen Perusahaan-perusahaan Manufaktur yang Terdaftar di Bursa Efek Indonesia”. E-Jurnal Manajemen Unud, 4(11), 3962-3990. 